Sharon Macdonald and Paul Basu (red.): Exhibition Experiments. Blackwell Publishing Ltd., 2007.

ISBN 978-1-4051-3076-9. 239 sider.

Antologien "Exhibition Experiments" er redigeret af englænderne Sharon Macdonald og Paul Basu, og kan ses i forlængelse af en række af publikationer, der på forskellig vis forsøger at forstå museet og de museale processer i det 21 århundrede. Bogen sætter fokus på udstillingsvirksomhed, og er et konstruktivt og inspirerende bidrag til diskussionen om, hvordan man kan udvikle og gentænke udstillingen som medie. I stedet for at betragte udstillingen som et instrument til videreformidling af eksisterende information, ses den som et rum, hvor der eksperimenteres og genereres ny viden. I denne anmeldelse perspektiveres bogen og nogle af de centrale problemstillinger, som den præsenterer, bliver diskuteret. Sharon Macdonald og Paul Basu er henholdsvis professor i social antropologi ved Manchester University og lektor i antropologi ved Sussex University. Begge har udgivet flere museologiske publikationer, herunder Macdonalds "Companion to Museum Studies" fra 2006.

\section{ANTOLOGIENS KONTEKST}

De seneste årtier er der blevet sat spørgsmålstegn ved nogle af de helt grundlæggende kategorier, som museet opererer med såsom objektiv viden og repræsentation, og dermed er det fundament, som museumsinstitutionen blev baseret på i 1700 tallet, blevet udfordret. Da Peter Vergo i slutningen af firserne introducerede begrebet New Museology, så opsummerede og præciserede han den epistemologiske drejning, som også var nået til det museale 111 felt. Den nye museologi indebærer en teoretisk forankring af de processer, der foregår på museet, en accept af, at genstande tilskrives mening ud fra en bestemt kontekst, samt at museet eksisterer i en historisk og politisk og samfundsmæssig arena og ikke kan behandles isoleret. Konsekvensen er en mere selvrefleksiv museologisk praksis. Dette betyder også en debat af, hvad et museum er, hvilken rolle det skal spille i samfundet, og hvem det er til for (Vergo 1989). Efter den teoretiske åbning af det museale felt er litteraturen om emnet vokset enormt, og teorier fra forskellige fagdiscipliner er trukket ind og brugt $i$ undersøgelsen af, hvad der sker, eller ideelt set skulle ske, i mødet mellem museum, genstande og museumsbrugerne. Dette er også set i Danmark, hvor blandt andet Bruno Ingemann og Ane Hejlskov Larsen i 2005 publicerede antologien Ny Dansk Museologi. Derudover er der også foregået en udvidelse af det genstandsfelt, som museologien opererer indenfor, idet selve perceptionen af udstillinger og genstande er blevet en del af en museologisk analyse. Her er der sket en forskydning fra udstilling som et rum for repræsentation til et rum for handling eller performance. Dette beskrives i øvrigt af Camilla Jalving i bogen "Udstillinger - mellem flimmer og fokus", redigeret af Elisabeth Bodin og Johanna Lassenius. Det er netop "Exhibition Experiments" ærinde, på baggrund af disse nyere tanker omkring museologisk praksis, at komme med et bud på, hvordan udstillingsvirksomhed kan forstås i dag. Dette gøres ved at fokusere på feltet mellem museumsbrugeren og udstillingen og den synergi, der opstår i deres møde.

De i alt ti bidrag til antologien kommer fra flere meget anerkendte teoretikere og museumsfolk så som Mieke Bal, Peter Weibel og 
112 Bruno Latour, men der er også fra tekster af yngre skribenter og kunstnere, der har praktisk erfaring med eksperimentelle projekter. Ideerne i bogen er udsprunget af oplæg og debat fra en konference afholdt af Association of Social Anthropologists i Manchester i 2003, hvor Sharon Macdonald stod for en paneldebat med overskriften "Exhibition Experiments: Technologies and Cultures of Display". ${ }^{1}$ Flere af forfatterne i "Exhibition Experiments", inklusiv medredaktøren Paul Basu, deltog med oplæg, men andre er kommet til senere gennem det videre arbejde med emnet. På trods af, at de fleste af forfatterne er fra England, markerer bogen sig ved at adskille sig fra den store del af den engelske museologiske litteratur, der de sidste år har været præget af en politisk dagsorden, hvor museer og udstillinger skal begrundes ved deres læringspotentiale eller bidrag til social fremgang for en bestemt gruppe. Dette har skabt en veludviklet tradition, som især Eilean Hooper-Greenhill fra Leicester University har bidraget til, hvor det som den enkelte kan lære i udstillingen, kommer til at stå i centrum. ${ }^{2}$ Det bliver i høj grad et spørgsmål om hvad man kan få ud af en udstilling. "Exhibition Experiments" har i denne forbindelse et internationalt, måske især europæisk, islæt og koncentrer sig især om hvilken proces, der finder sted og hvordan den foregår. Denne modvægt til en stor del af den øvrige litteratur gør, at bogen er et forfriskende bidrag til feltet og fremstår, passende nok i øvrigt, som fagligt eksperimenterende.

\section{TEORI Og SelVRefLEKSion}

Artiklerne i "Exhibition Experiments" udfolder sig indenfor forskellige teoretiske retninger, men flere er inspireret af elementer fra ak- tør-netværk teorien, som den bliver præsenteret af den franske filosof og antropolog Bruno Latour. Han bidrager også til bogen med en artikel, der er udarbejdet sammen med Peter Weibel. Her diskuterer de to eksperimentelle kunstudstillinger, som de sammen har kurateret på Zentrum für Kunst und Medientechnologie i Karlsruhe, Tyskland 'Iconoclash' og 'Making Things Public'. Her var udgangspunktet (baseret på aktør-netværk teorien), at en udstilling består af en række aktanter, såsom genstande, mennesker, udsagn og installationer, der er sat sammen til en kunstig assemblage, der er betinget af tid og sted og aldrig kan gentages på nøjagtig samme måde. I denne sammenstilling, eller assemblage, opstår et netværk mellem aktanterne, der konstituerer oplevelsen af udstillingen. I de to udstillinger eksperimenterer Latour og Weibel dels med sammenstilling af genstande og deres forskellige betydninger og dels med offentligheden som et netværk af aktanter, der gensidigt påvirker hinanden. 'Iconoclash' bestod af en række meget forskelligartede genstande fra både kunst, videnskab og religion, der ikke havde været set sammen før, og som tilsammen gav udtryk for dels den magt, billedet som repræsentation har, men også hvordan det som billedet eller genstanden repræsenterer, kan fornys. 'Making Things Public' handlede om repræsentation og politik, og inkluderede blandt andet en installation i installationen. To mediekunstnere lavede en installation, hvor museumsbrugernes adfærd blev registreret og gennem dette påvirkede blandt andet udstillingens lys og lyd. Begge udstillinger iscenesatte således to af de problematikker, der ligger til grund for udstillingsvirksomhed nemlig genstandenes forhold til repræsentation, samt den måde museumsbrugere og andre aktanter kontinuerligt påvirker det net- 
værk, som udstillingen er. Udstillingerne er således selvrefleksive, idet de dels behandler et emne, men også problematiserer udstillingen som medie. Selvrefleksion er et gennemgående tema i antologien. Paul Basu bruger labyrinten som billede på den måde, brugerne bevæger sig gennem udstillingen og debatterer hvordan museumsarkitektur af for eksempel Daniel Libeskind kan bruges til at forstyrre denne proces og dermed er med til at pege på udstillingen som udstilling.

Et andet bidrag til antologien, der er inspireret af netværkstanken er artiklen af Bernd Kraeftner, Judits Kroell og Isabel Warner, der beskriver udviklingen og udførelsen af projektet Xperiment! Projektet var et forskningsprojekt om genmodificeret ris, hvor distinktionen mellem lægfolk og ekspert blev opløst gennem dialog og samtale med museumsbrugerne, og bestod blandt andet i en kortlægning af de relationer eller det netværk, som projektet optrådte indenfor. På samme måde forklarer Nuno Porto i sin artikel, med henvisning til Latour, at udstillingen (netværket) er en kulturel mediation og foreslår, at man bruger betegnelsen installation for at understrege denne mediering og markere at konteksten er medskaber af det, som der præsenteres indenfor den. Denne aktive mediering er også central for Michelle Henning, der beskriver den indflydelse introduktionen af new media, har på udstillingen. Forståelsen og betydningen af udstillingen som begreb ændrer sig, fordi delene indenfor begrebet gør. Og det er ikke bare genstande og ny teknologi, der kan påvirke forståelsen af hvad en udstilling er. Kontinuerligt udskiftes dele af det netværk, som en udstilling består af, fordi museumsbrugerne aldrig er de samme. Denne medskaben af betydning ses i de fleste øvrige artikler, men er især tydelig hos Mieke Bal, Paul Basu og Alexa
Fäber, der på forskellig vis undersøger processen for denne medskabelse.

\section{EKSPERIMENTET SOM FORM}

Omdrejningspunktet i antologien er som beskrevet udstillingen som eksperiment. Men hvori ligger det eksperimentelle? Og kunne man ikke ud fra et perceptionsperspektiv hævde, at alle udstillinger altid er eksperimenter, fordi man ikke fuldstændigt kan kontrollere museumsbrugerens reception af udstillingen? Weibel og Latours to udstillinger bruger flere af de metoder og strategier, der er typiske i flere af de projekter, der bliver præsenteret $\mathrm{i}$ "Exhibition Experiments". Både kunstnere og kuratorer opgiver at formidle et facit, men sætter derimod deres egne interesser på spil i forhold til at skabe et komplekst rum, hvor der i stedet for svar stilles spørgsmål, og hvor der inviteres til debat. Weibel og Latours mål for udstillingerne beskrives således:

Challenging the "sacrosanct autonomy" of a singular curatorial vision, which typifies the hierarchical structure of much exhibitionary practice, Weibel and Latour's exhibitions are thus also experiments in heteronomy. Rather than seeking agreement and a neat convergence of purpose, Weibel and Latour describe the desired outcome of these assemblages as the production of "interference patterns", which as physicist experimenting with wave forms will explain, can be both constructive and destructive (Weibel og Latour 2007: 10).

Udstillingen udgør således et mødested mellem diverse aktanter, der har indflydelse på hinanden. Målet er ikke at sprede en bestemt slags viden, genereret af eksperter, men derimod skabe et rum, der åbner op for modsigelser og kompleksiteter. Det handler således 
114 ligeså meget om det man ikke ved, som det man ved. Det eksperimentelle ligger således hos Weibel og Latour dels i ophævelsen af afsender og modtager roller og dels i, at der ikke er et bestemt budskab, men at der skabes en åbning til et komplekst felt. Mieke Bal fokuserer i hendes bidrag også på, at udstilling kan vise andet end veltilrettede svar. Hun analyserer Ydessa Hendeles udstilling "Partners" i Haus der Kunst i München, og koncentrerer sig især om den følelse eller fornemmelse, som brugeren skaber når hun eller han bevæger sig gennem udstillingen. Budskabet er således mere en stemning end egentlig viden.

Begge disse forstålser af hvad en udstilling skal ligger umiddelbart langt fra en traditionel opfattelse af en udstilling, men at betragte udstillingen som et eksperiment har en historisk dimension, som Macdonald og Basu redegør for i deres indledning. De forklarer, at siden 1600 tallet har det videnskabelige eksperiment, på samme måde som udstillingen, bestået $\mathrm{i}$ at sammenstille forskellige apparater, mennesker, metoder osv. for at gøre noget usynligt synligt og afdække en sandhed. Derudover beskriver de, hvordan der i 1600 tallet blev udført videnskabelige eksperimenter på Ashmolean museet i Oxford. Men den egentlige grund til at lave sammenstillingen i dag skal nærmere findes i den eksperimentelle antropologi, og den inspiration museologien (og andre discipliner) har fundet $\mathrm{i}$ antropologien de seneste år, hvilket Basu og Macdonald også forholder sig til i deres velskrevne indledning. Her bliver udstillingen forstået som et rum, hvor mennesket udfolder sig socialt og kulturelt $\mathrm{i}$ interaktion med arkitektur og genstande. Udstillingen kan på den måde blandt andet ses som et 'designet' eksperiment, hvor mennesket, og den måde skaber vi betydning og mening på, kan studeres. Derudover har de etnologiske selvrefleksive forskningsmetoder og problematikken med at betragte 'den anden' haft stor teoretisk indflydelse på den nye museologi. Til dette kan tilføjes, at der i Bruno Latours udgave af aktør-netværk teorien, netop sker en antropologisering af den videnskabelige eksperimentelle metode, og det er denne, der i "Exhibition Experiments", bliver overført på udstillingen. Dette betyder også, at det meget kontrollerede og neutrale rum, som et eksperiment traditionelt set skulle bestå indenfor, bliver åbnet, idet der anerkendes, at aktanterne består i en historisk kontekst.

Udover forfatterne i "Exhibition Experiments" er der andre, der beskæftiger sig og har beskæftiget sig med udstillingsrummet som et eksperiment eller laboratorium. Tony Bennett skrev i 2005 en artikel i tidsskriftet Cultural Studies, som han kaldte 'Civic Laboratories', hvor han ud over selv at bruge begrebet, identificerer flere teoretikere, der også har behandlet emnet, herunder Donald Preziosi. Bennett trækker også på Latours teori i denne artikel, og artiklen er skrevet i forbindelsen med et forskningsprojekt om sociokulturel forandring, som Manchester University og Open University i London samarbejder om, og det ville have været interessant, hvis nogle af forfatterne i "Exhibition Experiments" havde forholdt sig til hans ideer eller refereret til ham. ${ }^{3}$ Bennetts tanker er ellers interessante i forhold til flere af de beskrevne projekter $i$ antologien som for eksempel Weibel og Latours udstillingsprojekter eller Bernd Kraeftner, Judith Kroell og Isabel Warners projekt Xperiment!, hvor et forskningsprojekt på forskellig vis debatteres med offentligheden. Her ville overvejelser om magtforholdene $i$ et netværk være vedkommende, men på trods af den selvrefleksivitet der fremlægges i forhold til, hvad en udstilling er, mangler der en overvejelse af, 
hvad det vil sige at stå for konstruktionen og opbygningen af en udstilling og de valg, der derigennem nødvendigvis er taget. Bennett berører dette ved at koble et magtbegreb med aktør-netværk teorien (Bennett 1995:1).

\section{Afsender, MOdTAGER Og VIDENSBEgREBET}

Udover de teoretiske overvejelser om udstillingen som eksperiment, er der i Danmark de senere år blevet præsenteret museale formidlingstiltag, der sammenligner deres praksis med laboratoriets, for eksempel Unges Laboratorier for Kunst på Statens Museum for Kunst. Her bruges ordet laboratorium til at understrege den vidensproduktion, der sker $\mathrm{i}$ arbejdet med kunsten, hvilket peger mod den opløsning af afsender- og modtagerforholdet, der ligger i hele eksperimenttanken. Samtidig iscenesættes museumsbrugerne som dem, der orkestrerer de eksperimenter, der finder sted i laboratoriet. Denne tilgang findes også hos Inge Merete Kjeldgaard, direktør for Esbjerg Kunstmuseum, når hun betegner museumsbrugerne som laboranter i museets æstetiske laboratorium (Laversen 2004). Sammensmeltningen af afsender og modtagere anfægter det encyklopædiske vidensbegreb, som blandt andet Kirsten Hastrup har problematiseret (Hastrup 1999). Museet råder ikke over en autonom viden, der kan indoptages af museumsbrugerne, viden er derimod situeret og noget, der opstår i relationerne mennesker og objekter. I "Exhibition Experiments" beskriver Latour og Weibel det således: “[...] the viewer becomes another actant in the field of enactment, and have the same rights as all others" (Latour og Weibel 2007:107). Paul Basu diskuterer i sin artikel dette ud fra en lidt anden vinkel. Med udgangspunkt i Paul Ricoeurs forståelse af narrativitet, ser Basu percep- tionen af udstillingen, som den historie museumsbrugeren skaber ved at bevæge sig gennem udstillingen. Museumsbesøget er således en række sekvenser, der sættes sammen i en personlig sammenhæng, uden mulighed for at kunne gennemskue helheden. Brugeren bliver i den forbindelse til den aktive medskaber af den viden, som han får gennem udstillingen. Tankerne om modtager og afsender og de konsekvenser det har for vidensbegrebet, er udfordrende for de forsknings- og vidensbaserede udstillinger, der stadig er tradition for på de fleste museer. I forhold til de danske eksperimentelle formidlingstiltag, kan man sige, at "Exhibition Experiments" går et skridt videre og overfører det nye vidensbegreb på, ikke bare en del af museets virksomhed, men på museet som helhed og på udstillingerne som særdeleshed. Hans Dam Christensen har flere gange problematiseret en generel mangel på teoretisk fundering og selvrefleksion i forskningsbaserede udstillinger i Danmark (Dam Christensen 2005: 263-277). Hans synspunkt han selvfølgelig diskuteres, men de metoder og strategier, der præsenteres i antologien, viser hvordan forskning og udstilling kan kobles.

Opsummerende kan man sige, at "Exhibition Experiments" beskriver mange af de problemstillinger, som museumsinstitutionen står overfor i dag, og flere af de bud, der gives på hvordan vi kan forny udstillingsmediet er relevante, teoretisk velfunderede og overbevisende. Der er naturligvis også problemer i bogen. Jeg har kort været inde på den manglende diskussion om magt og dermed den måske lidt for optimistiske tanke om udstillingen som det åbne netværk. Derudover kunne man stille spørgsmålet om hvordan museets moralske ansvar, hvis der eksisterer et sådant, vil forholde sig til denne udvikling. Og sidst, men ikke 
116 mindst, vil det være relevant at uddybe den formidlingsmæssige konsekvens, det vil have at lade genstande 'tale' direkte til museumsbrugeren og undvære den didaktiske præsentation af en udstilling, som vi trods alt er forvendte med. Præcist som de eksperimenterne udstillinger og projekter, der beskrives i bogen, fungerer den selv ved at åbne et komplekst felt, hvor man ender med mindst lige så mange spørgsmål som svar.

\section{NOTER}

1. For mere information om konferencen se http://www.theasa.org/conferences/asa03/panels/macdonald.htm

2. Se Hooper-Greenhill. E. 2007. Museums and Education: Purpose, Pedagogy, Performance, Routledge, London Hooper-Greenhill. E. 2000. Museums and the Interpretation of Visual Culture, Routledge, London. Hooper-Greenhill. E. (ed.) 1999. The Educational Role of the Museum (second edition), Leicester Museum Studies Readers, Routledge, London. Se også arbejdet 'Generic Learning Outcomes' (GLO) på http://www.inspiringlearningforall.gov.uk/ som Hooper-Greenhill har udviklet i samarbejde med Research Center for Museum and Galleries på Leicester University.

3. Tony Bennetts artikel kan downloades på http://www.cresc.ac.uk/ hvor man også kan læse mere om projektet.

\section{LITTERATUR}

Bennett, Tony. Civic laboratories: museums, cultural objecthood, and the governance of the social. Cultural Studies, Vol. 19, nr. 5: 521-547.

Dam Christensen, Hans. Museumsudstillinger uden forskning? Betragtninger over forskningens vidensorganisation på kunstudstillinger, in: Ane Hejlskov Larsen og Bruno Ingemann (eds.). Ny museologi i Danmark, Aarhus Universitets Forlag: Århus 2005: 1-18.

Hastrup, Kirsten. Viden om verden: en grundbog $i$ antropologisk analyse. Gyldendal: København 2004.

Jalving, Camilla. Fra objekt til begivenhed : om beskueren som deltager i udstillingens rum, in Elisabeth Bodin og Johanna Lassenius (eds.). Udstillinger mellem fokus og flimmer - en antologi om udstillingsmediet, Multivers: København 2006: 15-40.

Lavrsen, Lasse. Et æstetisk laboratorium. Information. 13 april 2004.

Vergo, Peter (red.): The New Museology. Reaktion Books, London 1989.

Weibel, Peter og Latour, Bruno. Experimenting with Representation: Iconoclash! and Making Things Public, in Sharon Macdonald and Paul Basu (eds.): Exhibition Experiments, Blackwell Publishing Ltd., 2007: 94-108.

Mette Houlberg Rung. Ph.d. stipendiat ved Statens Museum for Kunst, DK og University of Leicester, UK.

Adresse; Statens Museum for Kunst www.smk.dk

Sølvgade 48-50, 1307 København K $T+4533748414$

E-mail:mette.houlberg@smk.dk 